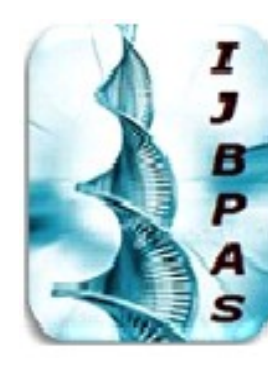

International Journal of Biology, Pharmacy and Allied Sciences (IJBPAS)

'A Bridge Betusen Caboratory and QRendo'

WwW.ijbpas.com

\title{
FACTORS INFLUENCING EMPLOYEES PERFORMANCE IN OUT SOURCING INDUSTRY AND IMPACT ON EMPLOYEES
}

\author{
NIKITA CHITLANGIA \\ Symbiosis Institute of Business, Management Pune Symbiosis International(Deemed \\ University), Pune, India \\ "Corresponding Authors: E Mail: Nikita.chitlangia.mba22@associates.sibmpune.edu.in \\ Received $19^{\text {th }}$ May 2021; Revised $4^{\text {th }}$ June 2021; Accepted $15^{\text {th }}$ July 2021; Available online $25^{\text {th }}$ Sept. 2021 \\ https://doi.org/10.31032/IJBPAS/2021/10.9.1025
}

\begin{abstract}
The last two decades have witnessed a rapid increase in the globalization of business. Developments in the fields of information technology, manufacturing technology, transportation, trade liberalization, emergence of new markets and increase in foreign direct investments have contributed significantly in this regard. The concept of a 'global village' has now become a reality.

The Indian business Process Outsourcing industry is in the throes of evolutionary change as the US recession finally begins to take its toll. The industry is looking at various strategies and technologies to survive and thrive amid growing pressure of the US recession.

The present study will be conducted with the objective to analyze the impact of economic slowdown on the employee's performance of BPO sector in India. Therefore, In order to achieve this objective a self administered questionnaire will be designed to analyze the employee's performance due to the impact of economic slowdown, level of job security and other related conditions.
\end{abstract}

Keywords: BPO, employee's performance, economic slowdown, Recession 


\section{INTRODUCTION}

The overall goal of business organizations is to search organizational resource talent. In case of service industry as it is universally accepted that employees are the vital element for better productivity. In case of BPO industry the functioning of companies depend upon the capabilities of Human resources. It is recommended that inside resources of any Firm influences its success and competitive advantage.

According to the resource based View (RBV) of the firm seeks to explain the variance in talent acquired by firms by focusing on the different sets of organizational resources acquired as a source of their success parameters (Park, 2001). Globalization now a day's remove the barriers all over the world results in to free flow of Foreign capital, human resources, growth of multinational institutions, cross-national mergers and acquisitions, changes in institutional rules governing ownership and investment and employability etc. But as the foreign companies expanding in any country such as India, various phases of business cycle oscillates form the harmonic vibrations for the economy with the means of Economic Recession.

Recession is defined as "a slump in

economy of a country for a minimum of two quarters of a year" The U.S. based National Bureau of Economic Research (NBER) defines a recession more broadly as "a significant decline in economic activity spread across the economy, lasting more than a few months, normally visible in real GDP growth, real personal income, employment (non-farm payrolls), industrial production, and wholesale-retail sales.". The US market is strongly influenced by recession wave in 2008 during the period of January to October. At that time, the Employability aspect falls in this regards that 1.2 million of Jobs are eliminated .

"The recession has affected everybody in one way or another as families use lots of different strategies to cope with a new economic reality," said Mark Mather, associate Vice President of the nonprofit Population Reference Bureau. "Job loss--or the potential for job loss-- also leads to feelings of economic insecurity and can create social tension." "It's just the tip of the iceberg," he said, noting that unemployment is still rising. As USA is facing a visible recession in current times, it is evident that economists are in overdrive to review the fiscal statistics and give expert opinions. The stock markets have already created a 
panic situation in the country. The biggest lenders are now facing a cash crunch and for the first time they are also admitting it. Most of the credit has gone into housing, car, security and insurance schemes. Americans who have invested in such schemes have only their stocks to offer as collaterals and now are facing the brunt with embarrassing foreclosures. There has been no sustainable development in major sectors like housing, medical and small scale businesses. The US economy had reached its peak and is slowly going downhill. Jobs are being outsourced to other countries while Americans are themselves jobless. As Asian countries are getting more employment, even expatriates are returning home. India and China are major outsourcing backyards for the US. (Gupta ,2012)

Shadow of Recession on Indian Industries and Economy

Corporate Results reveals that the impact of US Recession was not stagnated in that economy only but also creates the remarkable footprints on the developing economies like India. After 2008 onwards the various industries of Indian economy were also shows variation in their profit margin and competitive advantage.

Various industries in India were affected by the Economic Wind storm but because of sound roots of these industries were able to retain. The Indian food market is estimated at a turnover of over US\$ 182 billion and accounts for about two third of the total Indian retail market. Further, the retail food sector in India is likely to grow from around US\$ 70 billion in 2008 to US\$ 250 billion by 2025 . Healthcare, which is a US\$ 35 billion industry in India, is expected to reach over US\$ 150 billion by 2022. The healthcare industry is interestingly poised as it strives to emerge as a global hub due to the distinct advantages it enjoys in clinical excellence and low costs. Like these retail and health care industry Business Process Outsourcing was also affected during this recession Period in India.

\section{Recession and Indian BPO Industry}

India is one of the most preferred and remarkable outsourcing destination country by most of the multinational companies. Indian IT's BPO industry has been increasingly putting its efforts for contributing to the domestic economy over the years. It is also providing valuable contribution to the services sector (NASSCOM, 2011). Though cost reduction and availability of skilled English-speaking employees have been the key growth 
drivers for this industry, many other factors such as access to talent, service quality, and productivity have kept the Indian IT's BPO industry competitive in the international and transnational market. Some of the Human Resource related issues receiving considerable attention in the BPOs are work conditions, organizational environment management-labor relationships, work force empowerment and work life balance. Work-life balance is the stability characterized by the balancing of an individual's life complexity and dynamism with environmental and personal resources such as family, community, employer, profession, geography, information, economics, personality, or values (Crooker $e t$ al, 2002)

The Business Process Outsourcing firms believe they will be less impacted by the global crisis than their counter partners like IT Companies, since they are involved in facilitating day-to-day operations. Currently, processing services account for $60 \%$ of the industry, while the rest comes from core services (business analysis, financial planning etc). Previously the ratio was $70: 30$ and it's likely to be in the 50:50 ranges in the coming time. Also, the share of voice-based services has fallen from $95 \%$ previously to $80 \%$ now and is expected to slide further. India will not be much affected, since it accounts for only $5 \%$ of the global voice market.

The major impact of recession or economic slowdown is with the small exporters and importers in the country as most of them are facing the problem of heavy duties. "The US slowdown will immensely hit the mid- sized IT companies and also the big players to some extent. The techno-savvy group will benefit as the IT hardware industry has decided to pass on the $4 \%$ across- the-board excise duty cut to consumers which will help bring down the prices of IT products like TFT monitors, printers and projectors as well as computers and notebooks. With this, desktops and notebooks will attract $8 \%$ excise duty, while all other hardware equipment would attract $10 \%$. The economic slowdown will mostly affect medium-sized IT-ITES companies. Indian IT-ITES companies have also undertaken labor-cost rationalization by getting rid of poor-performing workforces and tightening recruitment policies. Companies have also reduced the average age of their workforce in order to reduce cost and improve overall profitability. Companies may not be adding the kind of people that they were last year, but they are definitely getting better yield from existing 
employees. In addition, the slowdown has accelerated the desire of India-born professionals based in the US to return to their home soil.

While such IT professionals previously returned in hopes of being part of the Indian growth story, today the subprime crisis, slowing economy and fear of layoffs in the US are prompting these workers to look for opportunities in India. As a result, India's talent pool is getting richer and it could be only a matter of time before the Indian IT-ITES industry overcomes the problems posed by a US slowdown. In context of the IT industry, Nasscom had initially projected a 21-24 per cent growth rate for the current financial year, but the software association revised it downward in the wake of the global financial meltdown. According to a Nasscom spokesman, "IT industry has demonstrated time and again that it is resilient enough to deal with these challenges,"

The International Labor Organization (ILO) has presented the picture of reduction in employment across the world. In India, according to labor bureau, mining, metal and metal products, textile and garments, gems and jewellery, construction, transport and some segment of service sector (mostly, information technology and Business Process Outsourcing (BPO) services including private banks) has suffered much.

As it has been seen from the above information that whether the corporate entities are executing their activities during recession period but the extent of productivity and performance was under question mark. This may be because of economic parameters, organizational internal and external factors etc. Though during this recession period BPO industry executing their efforts to perform better but the employees and their opinion was key element to understand the impact of recession on BPO service industry.

\section{REVIEW OF LITERATURE}

The review of literature deals with the study of earlier available research work in the field of Service industry dealing with the various issues like the employees performance etc.

(Hans, 2009) examined the economic turbulence. The volatility of the developed economies has come to the developing economies in the era of transnationalisation. Wall Street is clearly impacting the Indian job market. Banks are folding up. Deals are getting postponed. Outsourcing Industry is feeling the insidious effect of banks going 
bout of business and everyone is trying to protect his/her job. He described how bad is the financial crunch, its ingredients, its impact on Indian economy in general and the banking and realty sectors in particular. Besides making an assessment of the current economic situation, the paper also analyzed some practical solutions to the problems at hand and the impending ones.

(Saxena, 2004) examined the some issues concerning outsourcing in order to provide nuance to some of the rhetoric. In particular, we paper discussed the US-India outsourcing history and reassess the key questions surrounding the subject. The empirical evidence is provided in order to support our main argument - that outsourcing has been going on for a while and that the risk to US job growth due to outsourcing is exaggerated. As framing the debate in strictly economic terms is difficult given that there are "real" winners and "real" losers caught in the crosstalk, the paper seeks to offer recommendations to help ease the socio-economic impact of outsourcing. (Das, 2010) examined the world economy crisis since 1930s. The crisis had affected almost all countries in the world. The emerging economies like India suffered through spillover effects. Industry and employment sector experienced a regressive jolt due to drying up of credit, squeezing of market and slowdown in demand. The social cost of the crisis is unemployment. This paper argues that in devising a proper policy for combating recession, not only bailout packages but also a mix of monetary and fiscal policy is required.

(Jayanthi, 2011) opined the work life balance among the Employers of service sector who have responded to the changing social and business environment and built Work- Life Balance policies into their culture have benefited tremendously. $\mathrm{He}$ analyzed the key need or reason for introducing Work- Life Balance policies in the organizations. Further he concluded that In India, there is a starting point is that organizations have recognized the need for and value of Work-Life Balance policies. An advantage that Indian industry will however have is learning's from the experiences of other countries in what has worked and what has not.

(Silva, 2011) analyzed the Business Process Outsourcing (BPO) and Information Technology (IT) industry in Sri Lanka, which is one of the countries that has gained confidence by reinventing its economy around. Outsourcing will reduce overheads and US and European companies will able 
to focus on their core business. Most of the school leavers and young workforce are employed in BPO companies in Sri Lanka. Staff retention and motivation are current challenges faced by BPO companies. High staff turnover will cost companies, by having to spend time and money for training $\&$ recruitment of staff. Also sustaining their performance levels is another challenge in routine working conditions. The study mainly focused on job satisfaction and performance of outsource staff and findings of the research will help IT/BPO companies in Sri Lanka to overcome the challenges that face current context.

\section{OBJECTIVES OF THE STUDY}

The main objective of the study is to find the important factors that affect the employee's performance of BPO sector in
India due to the economic slowdown.

\section{RESEARCH METHODOLOGY}

The present study consists of Primary data. The primary data is collected using the self administered questionnaire from the employees of BPO sector in New Delhi, Nodia and Gurgoan.

Nearly 150 questionnaires were distributed and 147 were collected in return. The questionnaire consisted of demographic profile of respondents and 20 statements. The respondents were asked to rate the questions on five point Likert scale whereas the statements were divided into highly dissatisfied (-2) to highly satisfied (+2) the factor analysis were run on the data collected.

\section{ANALYSIS AND DISCUSSION}

In this study, five demographic factors of the respondents namely age, Gender, working experience, Qualification and marital status had been studied.

\begin{tabular}{|c|l|c|c|}
\hline $\begin{array}{l}\text { Demographic } \\
\text { Characteristics }\end{array}$ & $\begin{array}{l}\text { Demographic } \\
\text { Variable }\end{array}$ & $\begin{array}{l}\text { No 0f } \\
\text { Respondents }\end{array}$ & Percentage of Respondents \\
\hline Gender & Male & 86 & 59 \\
\hline & Female & 61 & 41 \\
\hline Age & Less than 25yrs & 79 & 54 \\
\hline & $25-35$ yrs & 58 & 39 \\
\hline & $35-50$ & 8 & 5.4 \\
\hline & More than 50yrs. & 2 & 1.4 \\
\hline & & & 43 \\
\hline & UnderGraduate & 63 & 48 \\
\hline & Graduate & 71 & 8.8 \\
\hline & Post-graduate & 13 & 37 \\
\hline Marital Status & Married & 54 & 63 \\
\hline & Unmarried & 93 & \\
\hline Monthly & & & 1.4 \\
\hline Salary & Less Than 5000 & 2 & 10 \\
\hline & $5,000-10,000$ & 15 & 56 \\
\hline & $10,000-20,000$ & 82 & 33 \\
\hline & More than 20,000 & 48 & \\
\hline & & & \\
\hline
\end{tabular}


VI. RESULTS OF FACTOR ANALYSIS

Reliability analysis has been conducted on 27 variables and Cronbach Alpha is determined as 0.587 which indicates reliability of the scale. Table 1 shows the reliability statistics.

Kaiser- Meyer- Olkin (KMO) test measures the sampling adequacy and the appropriateness is computed as 0.521 that indicates adequacy of sample.

$>$ The overall significance of correlation matrices is tested with the Bartlett's test of spherecity significant at
$2 \%(\mathrm{p}<0.000)$ that supports the validity of data. Table 2 shows KMO measure the sampling adequacy and Bartlett's test of spherecity.

Seven factors were extracted with the help of factor analysis, altogether explaining the $62.949 \%$ of the variance in the data.

Table 1: Reliability Statistics

\begin{tabular}{|c|c|}
\hline Cronbach's Alpha & N of Items \\
\hline .587 & 27 \\
\hline
\end{tabular}

Table 2: KMO and Bartlett's Test

\begin{tabular}{|l|l|r|}
\hline \multicolumn{2}{|l|}{ Kaiser-Meyer-Olkin Measure of Sampling } & .521 \\
Adequacy. & \\
\hline Bartlett's Test of Sphericity & $\begin{array}{l}\text { Approx. Chi- } \\
\text { Square }\end{array}$ & 364.311 \\
\cline { 2 - 3 } & Df & 105 \\
\cline { 2 - 3 } & Sig. & .000 \\
\hline
\end{tabular}


Table No 3: Total Variance explained

\begin{tabular}{|c|c|c|c|c|c|c|c|c|c|}
\hline \multirow[t]{2}{*}{ Component } & \multicolumn{3}{|c|}{ Initial Eigen ralues } & \multicolumn{3}{|c|}{$\begin{array}{c}\text { Extraction Sums of Squared } \\
\text { Loadings }\end{array}$} & \multicolumn{3}{|c|}{$\begin{array}{c}\text { Rotation Sums of Squared } \\
\text { Loadings }\end{array}$} \\
\hline & Total & $\begin{array}{c}\% \text { of } \\
\text { Variance }\end{array}$ & $\begin{array}{c}\text { Cumulative } \\
\%\end{array}$ & Total & $\begin{array}{c}\% \text { of } \\
\text { Variance }\end{array}$ & $\begin{array}{c}\text { Cumulative } \\
\%\end{array}$ & Total & $\begin{array}{l}\% \text { of } \\
\text { Variance }\end{array}$ & $\begin{array}{c}\text { Cumulative } \\
\%\end{array}$ \\
\hline 1 & 7.044 & 27.094 & 27.094 & 7.044 & 27.094 & 27.094 & 4.439 & 17.073 & 17.073 \\
\hline 2 & 2.439 & 9.381 & 36.475 & 2.439 & 9.381 & 36.475 & 2.633 & 10.126 & 27.199 \\
\hline 3 & 2.022 & 7.777 & 44.253 & 2.022 & 7.777 & 44.253 & 2.205 & 8.479 & 35.678 \\
\hline 4 & 1.622 & 6.237 & 50.490 & 1.622 & 6.237 & 50.490 & 2.099 & 8.073 & 43.752 \\
\hline 5 & 1.372 & 5.278 & 55.769 & 1.372 & 5.278 & 55.769 & 1.685 & 6.480 & 50.231 \\
\hline 6 & 1.309 & 5.036 & 60.805 & 1.309 & 5.036 & 60.805 & 1.679 & 6.459 & 56.691 \\
\hline 7 & 1.135 & 4.364 & 65.169 & 1.135 & 4.364 & 65.169 & 1.627 & 6.258 & 62.949 \\
\hline 8 & .920 & 3.872 & 69.041 & & & & & & \\
\hline 9 & .902 & 3.468 & 72.509 & & & & & & \\
\hline 10 & .885 & 3.405 & 75.914 & & & & & & \\
\hline 11 & .765 & 2.943 & 78.857 & & & & & & \\
\hline 12 & .711 & 2.734 & 81.591 & & & & & & \\
\hline 13 & .622 & 2.394 & 83.985 & & & & & & \\
\hline 14 & .568 & 2.184 & 86.169 & & & & & & \\
\hline 15 & .521 & 2.004 & 88.173 & & & & & & \\
\hline 16 & .499 & 1.920 & 90.093 & & & & & & \\
\hline 17 & .441 & 1.697 & 91.790 & & & & & & \\
\hline 18 & .335 & 1.290 & 93.081 & & & & & & \\
\hline 19 & .311 & 1.197 & 94.278 & & & & & & \\
\hline 20 & .293 & 1.126 & 95.403 & & & & & & \\
\hline 21 & .269 & 1.034 & 96.437 & & & & & & \\
\hline 22 & .233 & .896 & 97.334 & & & & & & \\
\hline 23 & .213 & .820 & 98.153 & & & & & & \\
\hline 24 & .209 & .810 & 98.990 & & & & & & \\
\hline 25 & .204 & .785 & 98.938 & & & & & & \\
\hline 26 & .154 & .594 & 99.532 & & & & & & \\
\hline 27 & .122 & .468 & 100.000 & & & & & & \\
\hline
\end{tabular}


Table No 4: Summarized Results of Factor Analysis

\begin{tabular}{|c|c|c|c|c|}
\hline $\begin{array}{l}\text { Sr. } \\
\text { No }\end{array}$ & Factor-wise Dimensions & $\begin{array}{l}\text { Eigen } \\
\text { Value } \\
\end{array}$ & $\begin{array}{l}\% \text { of variance } \\
\text { explained }\end{array}$ & $\begin{array}{l}\text { Cumulative } \% \text { of } \\
\text { variance } \\
\text { explained }\end{array}$ \\
\hline$F 1$ & Availability of leave & \multirow{6}{*}{4.439} & \multirow{6}{*}{17.073} & \multirow{6}{*}{17.073} \\
\hline A & Problem in getting Leave & & & \\
\hline $\mathrm{B}$ & $\begin{array}{l}\text { Additional Leave in exchange for } \\
\text { reduced pay }\end{array}$ & & & \\
\hline $\mathrm{C}$ & Flexible break provision & & & \\
\hline D & Shorter working week & & & \\
\hline $\mathrm{E}$ & Half-time work & & & \\
\hline$F 2$ & Top Management Support & & & \\
\hline A & Support from top management & \multirow{3}{*}{2.633} & \multirow{3}{*}{10.126} & \multirow{3}{*}{27.199} \\
\hline $\mathrm{B}$ & Support from colleagues & & & \\
\hline $\mathrm{C}$ & Workinghours & & & \\
\hline$F 3$ & PersonalLife Adjustment & & & \\
\hline A & Adequate sleep and rest & \multirow{3}{*}{2.205} & \multirow{3}{*}{8.479} & \multirow{3}{*}{35.678} \\
\hline $\mathrm{b}$ & $\begin{array}{l}\text { I get enough time to give mys elf, } \\
\text { exercise, hobbies and sports }\end{array}$ & & & \\
\hline $\mathrm{C}$ & $\begin{array}{l}\text { I gat adequate time to spend with } \\
\text { family and friends }\end{array}$ & & & \\
\hline F6 & Interpersonal Relationship & & & \\
\hline A & Support from colleagues & & & \\
\hline B & $\begin{array}{l}\text { I get enough time to interact with } \\
\text { colleagues and Management }\end{array}$ & 1.679 & 6.459 & 56.691 \\
\hline C & $\begin{array}{l}\text { I am able to build strong } \\
\text { relationship with Colleagues and } \\
\text { Management }\end{array}$ & & & \\
\hline $\mathrm{F} 7$ & Work Efficiency & & & \\
\hline A & $\begin{array}{l}\text { Work Efficiency and effectiveness } \\
\text { during the recession time }\end{array}$ & 1.627 & 6.258 & 62.949 \\
\hline
\end{tabular}




\section{EXTRACTION OF FACTORS}

Factors are extracted on the basis of Eigen Values. Factors with Eigen Value greater than 1 are retained, other factors are not included. An Eigen Value represents the amount of variance associated with in the factor. From table, seven factors have been extracted and the total variance explained by all the factors taken together is $62.949 \%$. The remaining is due to other factors beyond the scope of the study. Following is the description of the factors derived.

F1 Availability of leave: This is the most important factor on which the five variables have loaded and it explains $17.073 \%$ of the variance with eigen value 4.439 . It deals with Problem in getting Leave, Additional Leave in exchange for reduced pay, Flexible break provision, Shorter working week and Half-time work.

F2 Top Management Support: This is the most second important factor on which the eight variables have loaded and it explains $\mathbf{1 0 . 1 2 6} \%$ of the variance with eigen value 2.633 . Three variables have been loaded onto are Access to Support from top management, Support from colleagues and Working hours.

F3 Personal Life Adjustment: Three variables are loaded on this factor Adequate sleep and rest, I get enough time to give myself exercise, hobbies and sports, I get adequate time to spend with family and friends explaining the $\mathbf{8 . 4 7 9} \%$ of the variance and eigen value $\mathbf{2 . 2 0 5}$

F4 Working Environment: This factor explains of the

8.073 variance. Four variables are loaded onto this i.e. Adjust with change of Organizational policies, rules etc., Flexitime, Adequate sleep and rest and successfully achieve the targets.

F5 Job Security: Three variables are loaded onto this factor i.e. Employee performance feedback, Free flow of information regarding organizational future plans and Talent recognisation.

F6 Interpersonal Relationship: This is the sixth factor explaining the $6.459 \%$ of the variance. The loadings for the variables are interaction with colleagues and Management, Support from colleagues and strong relationship with Colleagues and Management.

F7 Work Efficiency: This is the seven factor and only one variable is loaded under this factor i.e. Work Efficiency and effectiveness during the recession time.

\section{CONCLUSION}

In case of BPO industry the work of employees is not usual. The Employees are in huge pressure to achieve their prescribed 
targets along with Day/Night shift Mechanism. They have to maintain the proper balance in their professional as well personal life with greater extent. Hence during recession period they try to make proper equilibrium between various factors which affect their performance so that productivity remains same. In this research Paper an effort is made to analysis those major factors such as Problem in getting Leave, Additional Leave in exchange for reduced pay, Flexible break provision, Shorter working week and Half-time work, Access to Support from top management, Support from colleagues and Working hours which employees perceive that they affect their performance. For Future research, Work can be done to understand that what kind of Systematic mechanism, techniques and training Programs can be used to Create positive Impact on employee's

performance in case of undesirable conditions like Recession.

\section{REFERENCES}

[1] Park, Hyeon Jeong. Gardner, Timothy and Wright, Patrick. (2001), "The True Resource in Strategic Human Resource Management: Insights From the Asia Pacific Region" http://digitalcommons.ilr.cornell.edu/ cahrswp.
[2] Hans, Dr. V. Basil. (2009), "Global Meltdown and India - Issues, Concerns and Challenges", Presented at UGC sponsored two-day National Seminar on India- Sixty Years In A Nation's Life, BESANT EVENING COLLEGE ,M.G. Road Mangalore, Karnataka State, INDIA.

[3] Rishi, Meenakshi. and Saxena, Sweta. (2009), "Is Outsourcing Really As Bad As It Is Made To Sound" Seattle University and University of Pittsburgh.

[4] Das, Sanjit Kumar. And Chakrabarty, Indranil. (2010)." Global Economic Recession and its Impact on Industry and Employment In India" Vidyasagar University Journal of Commerce Vol. 5,Issuse No.2, pp.no.63-68.

[5] Gupta, Anurag. (2012), "Business in times of economic recession: impact and opportunities in the Indian telecom and IT sector", http://www. freepatentsonline.com /article/ Indian-Journal-Economics-

[6] Business/267808356.html

[7] Jayanthi, Maria Angelin. And Santhi, N. (2011), "Study On Work Life Balance Among Service Sector" ,

[8] SRM Management Digest, Vol.9, 
ISSN 0973-6905

[9] Silva, H.A.R.N. Udawatta, L.and Nanayakkara, V. (2011), “ A Study Of IT/BPO Industry And Factors Influencing Their Performance" , SAITM Research Symposium on Engineering Advancements

[10] Bruck, C. et al. (2002). The Relation between Work- Family Conflict and Job Satisfaction: A Finer-Grained Analysis. Journal of Vocational Behavior, Vol.60 (3), pp.336-353. 